\title{
Relationship between Nonprotein Nitrogen and Total Nitrogen in Chickpea (Cicer arietinum L.) Seed
}

Nonprotein nitrogen (NPN) in chickpea seeds was extracted by using $80 \%$ ethanol and different concentrations of trichloroacetic acid $\left(\mathrm{Cl}_{3} \mathrm{AcOH}\right) . \mathrm{Cl}_{3} \mathrm{AcOH}$ extracted considerably higher amounts of nitrogen than did ethanol. NPN in 98 germ plasm accessions of chickpea was determined by use of $\mathrm{a} \mathrm{Cl}_{3} \mathrm{AcOH}$ concentration of $10 \%(\mathrm{w} / \mathrm{v})$. NPN as percentage of meal nitrogen varied between 5.84 and 16.48. A positive and highly significant correlation $(0.802)$ was obtained between percentage of the total meal nitrogen and percentage of NPN in the meal. NPN, expressed as percentage of total meal nitrogen, showed a lower but appreciable correlation (0.468) with percentage of the total nitrogen in the meal.

Chickpea (Cicer arietinum L.) is a crop of economic importance and also an important source of protein in the diet of people in India as well as in other countries.

Total protein content in the diet of people in the developing countries deserves special attention as large segments of people in these areas are reported to suffer from protein-calorie malnutrition. In the normal procedure for estimating protein intake, nitrogen content is obtained by the standard micro-Kjeldahl method and a factor is used to convert the figure into protein percentage. In this process, it is tactitly assumed that all the nitrogen is associated with the protein. But, in fact, this is not true. Therefore, any large variation in NPN content would affect the estimated protein of the sample and would consequently affect the estimated protein intake in the diet. However, some of the NPN probably consists of amino acids and peptides which would be utilized. Attempts have been made to determine NPN in various crops (Bell, 1963; Boulter and Davis, 1968: Bhatty, 1972; Millerd, 1972). This study was conducted to determine the variation, if any, that might exist in chickpea samples and to identify the relationship between NPN and crude protein nitrogen in chickpea.

\section{EXPERIMENTAL SECTION}

Materials. From the chickpea germ plasm lines grown at the ICRISAT Center during 1975-1976 and analyzed for protein content in our laboratory, 98 accessions with a wide range in crude protein were selected for this study. Whole-seed samples were ground to a fine meal (60-mesh sieve) and oven dried at $70^{\circ} \mathrm{C}$ overnight.

Methods. Direct extraction of meal NPN, using different $\mathrm{Cl}_{3} \mathrm{AcOH}$ concentrations $(1,5,10,15$, and $20 \%)$ and $80 \%$ ethanol, was carried out on one sample in order to determine the variability in the amount of nitrogen extracted. Five hundred milligrams of the sample dispersed in $15 \mathrm{~mL}$ of solvent was shaken in a centrifuge bottle by using a reciprocating shaker for $1 \mathrm{~h}$ at room temperature. The insoluble material was sedimented by centrifugation (12000 $\mathrm{g}$ for $15 \mathrm{~min})$. The residue was washed twice with the solvent with $0.5-\mathrm{h}$ shaking each time and then centrifuged to separate the insoluble material. The supernatants were combined and the final volume was made up to $25 \mathrm{~mL}$. Nitrogen content in the meal sample and in the supernatants was determined by the standard microKjeldahl procedure (Association of Official Analytical Chemists, 1970).

To determine the levels of NPN in different germ plasm lines, a $\mathrm{Cl}_{3} \mathrm{AcOH}$ concentration of $10 \%$ (w/v) was used. The extraction procedure was same as that described above. It was observed that further extraction of the residue with $\mathrm{Cl}_{3} \mathrm{AcOH}$ did not yield any additional soluble nitrogen. Attempts were also made to find out the amount
Table I. Effect of Ethanol and $\mathrm{Cl}_{3} \mathrm{AcOH}$ on N Solubility of Chickpea Meal ${ }^{a}$

\begin{tabular}{|c|c|c|c|}
\hline \multirow[b]{2}{*}{ solvent } & \multirow{2}{*}{$\begin{array}{c}\text { conen } \\
\%\end{array}$} & \multicolumn{2}{|c|}{$\begin{array}{c}\text { nonprotein nitrogen } \\
\text { as } \% \text { of }\end{array}$} \\
\hline & & $\overline{\text { meal }}$ & total nitrogen \\
\hline $\begin{array}{l}\text { ethanol }(v / v) \\
\mathrm{Cl}_{3} \mathrm{AcOH}(\mathrm{w} / \mathrm{v})\end{array}$ & $\begin{array}{r}80 \\
1 \\
5 \\
10 \\
15 \\
20\end{array}$ & $\begin{array}{l}0.12 \\
0.57 \\
0.33 \\
0.23 \\
0.27 \\
0.29\end{array}$ & $\begin{aligned} 3.69 & \pm 0.22 \\
16.92 & \pm 0.44 \\
9.58 & \pm 0.38 \\
6.86 & \pm 0.11 \\
7.95 & \pm 0.26 \\
8.58 & \pm 0.18\end{aligned}$ \\
\hline
\end{tabular}

${ }^{a}$ Defatted whole-seed sample of chickpea (cv. G. 130). Mean of eight determinations.

of protein nitrogen solubilized by $10 \% \mathrm{Cl}_{3} \mathrm{AcOH}$ using the biuret procedure.

\section{RESULTS AND DISCUSSION}

$\mathrm{Cl}_{3} \mathrm{AcOH}$ extracted more meal nitrogen than ethanol (Table I). This agrees with the results of a previous study (Bhatty and Finalalyson, 1973) in which nitrogen extraction from soybean and oilseed meal by use of ethanol was reported to be poor. However, it is also apparent from Table I that concentrations of 1 and $5 \% \mathrm{Cl}_{3} \mathrm{AcOH}$ extracted higher meal nitrogen than did $10 \% \mathrm{Cl}_{3} \mathrm{AcOH}$. Presumably, lower concentrations of $\mathrm{Cl}_{3} \mathrm{AcOH}$ extracted proteins in addition to NPN from the meal.

The aliquots of 1 and $5 \% \mathrm{Cl}_{3} \mathrm{AcOH}$ extracts were adjusted to a final concentration of $\sim 10 \%(\mathrm{w} / \mathrm{v})$ in order to find out whether the lower concentrations of $\mathrm{Cl}_{3} \mathrm{AcOH}$ had extracted proteins. As a result, proteins were precipitated from the extracts, indicating that the lower concentration of $\mathrm{Cl}_{3} \mathrm{AcOH}$ extracted proteins as well as NPN from the meal. Higher concentrations of $\mathrm{Cl}_{3} \mathrm{AcOH}$ have been reported to cause hydrolysis of seed proteins (Bhatty and Finalayson, 1973). In this study, extraction of the meal with $\mathrm{Cl}_{3} \mathrm{AcOH}$ concentrations up to $10 \%$ did not cause protein hydrolysis, as shown by the decreasing solubility of meal nitrogen. Slightly higher values for NPN were observed when a $20 \% \mathrm{Cl}_{3} \mathrm{AcOH}$ concentration was used (Table I). Extraction of more nitrogen by $20 \% \mathrm{Cl}_{3} \mathrm{AcOH}$ does not necessarily mean that hydrolysis occurred. This may also indicate that perhaps the proteins are soluble at $\mathrm{Cl}_{3} \mathrm{AcOH}$ concentrations above $10 \%$.

Having examined the effects of different concentrations of $\mathrm{Cl}_{3} \mathrm{AcOH}$ on nitrogen solubility of chickpea meal, we made further attempts to determine the amount of protein nitrogen solubilized by $10 \% \mathrm{Cl}_{3} \mathrm{AcOH}$. As mentioned eariler, the residue and supernatant obtained after $10 \%$ $\mathrm{Cl}_{3} \mathrm{AcOH}$ treatment were analyzed for their protein content by the biuret procedure and for total nitrogen by the micro-Kjeldahl procedure. It was observed that only $3 \%$ of the total protein was solubilized by $10 \% \mathrm{Cl}_{3} \mathrm{AcOH}$ while 
Table II. Correlation Coefficients between Total Nitrogen and Nonprotein Nitrogen in Ninety-eight Germ Plasm Accessions of Chickpea

\begin{tabular}{lccc}
\hline & range & mean & $\begin{array}{c}\text { correlation } \\
\text { coefficient } \\
\text { of } \% \text { total } \\
\text { component }\end{array}$ \\
\hline total N as \% of meal & $2.43-4.85$ & 3.58 & \\
NPN as \% of meal & $0.16-0.73$ & 0.36 & $0.802^{a}$ \\
NPN as \% of total N & $5.84-16.48$ & 9.84 & $0.468^{a}$ \\
a Significant at the $1 \%$ level. & &
\end{tabular}

$10.5 \%$ of total nitrogen of the meal was found in the supernatant. A positive reaction is obtained with the biuret reagent even with small peptides. Therefore, small peptides may be present as such in mature chickpea seeds. As a negligible amount of protein (peptides) was dissolved by $10 \% \mathrm{Cl}_{3} \mathrm{AcOH}$, it can be concluded that the values obtained by direct extraction using $10 \% \mathrm{Cl}_{3} \mathrm{AcOH}$ represent the NPN of the meal.

On the basis of the results of this investigation, a $\mathrm{Cl}_{3}$. $\mathrm{AcOH}$ concentration of $10 \%(\mathrm{w} / \mathrm{v})$, at which nitrogen solubility was observed to be minimal, was employed for the extraction of NPN in germ plasm samples. The means and ranges of total meal nitrogen and NPN in 98 germ plasm lines of chickpea are presented in Table II. Total meal nitrogen in these lines varied between 2.43 and $4.85 \%$, whereas NPN as percentage of the meal varied between 0.16 and 0.73 . A positive and highly significant correlation $[r=0.802$ (significant at the $1 \%$ level)] was obtained between percentage of the total meal nitrogen and percentage of the NPN of the meal. On the other hand, when expressed as percentage of the meal nitrogen,
NPN varied between 5.84 and 16.48 and showed a lower but appreciable correlation $[r=0.468$ (significant at the $1 \%$ level)] with the percentage of the total nitrogen in the meal. Therefore, whether expressed either as percentage of the meal or as percentage of the total nitrogen, NPN increased when the total nitrogen of the meal increased.

It is evident from these results that all nitrogen present in chickpea is not associated with seed protein, suggesting that NPN has to be taken into account if total protein content is to be measured accurately.

\section{ACKNOWLEDGMENT}

We are grateful to P.V Rao for technical assistance and Dr. L. J. G. van der Maesen for the supply of seed material.

\section{LITERATURE CITED}

Association of Official Analytical Chemists "Official Methods of Analysis", 11th ed.; AOAC: Washington, DC, 1970.

Bell, P. M. J. Sci. Food Agric. 1963, 14, 133.

Bhatty, R. S. Cereal Chem. 1972, 49, 729.

Bhatty, R. S.; Finalayson, A. J. Cereal Chem. 1973, 50, 329. Boulter, D.; Davis O. J. New Phytol. 1968, 67, 935.

Millerd, A., paper presented at a seminar held in the Division of Plant Industry, CSIRO, Canberra, March 1972, p 52.

Umaid Singh*

Ramamurthi Jambunathan

International Crops Research Institute for the Semi-Arid Tropics

Patancheru P.O.

Andhra Pradesh 502 324, India

Received for review August 29, 1980. Accepted January 9, 1981. Submitted as Journal Article No. 128 by the International Crops Research Institute for the Semi-Arid Tropics (ICRISAT).

\section{CORRESPONDENCE}

\section{On the Sorption of Neutral Organic Solutes in Soils}

Sir: Recently, Wahid and Sethunathan (1979) presented excellent data describing the sorption of the $\alpha, \beta$, and $\gamma$ isomers of hexachlorocyclohexane $(\mathrm{HCH})$ on a wide variety of soils. They found organic carbon to be the single most important soil property affecting $\mathrm{HCH}$ sorption. In the study, the expected linear dependence of sorption on organic carbon was factored into two linear branches with the "breakpoint" at $1.98 \%$ organic carbon. These data are amenable, however, to a simpler description and perhaps less misleading analysis.

The relative importance of organic carbon in the sorption of hydrophobic organic compounds is well established [see Kenega and Goring (1978) for a complete documentation]. The sorption partition coefficient, $K_{\mathrm{p}}$, or Freundlich $K$, when referenced to organic carbon (i.e., $K_{\mathrm{p}} / \mathrm{oc} \equiv K_{\mathrm{oc}}$ ) is highly independent of the soil or sediment, seldom varying more than a factor of 2 for nonpolar organics. (The fractional mass of organic carbon in the soil/sediment is denoted by oc.) Numerous $K_{o c}$ values for $\gamma$-HCH can be derived from the literature [see Farmer (1976) for a summary of the literature data)], and vary from 1000 to 2000 on soils and sediments ranging in organic carbon from 0.38 to $18 \%$. Also, for these types of organic compounds, Karickhoff et al. (1979) showed that excellent estimates of $K_{o c}$ can be derived from octanol/water distribution coefficients, $K_{\text {ow }}$. For unfractionated soils and sediments

$$
\log K_{\text {oc }} \approx \text { low } K_{\text {ow }}-0.39
$$

Kurihara et al. (1972) published $K_{\text {ow }}$ values for the $\alpha, \beta$, and $\gamma$ isomers of 6440,6250 , and 5200 , respectively, from which $K_{\mathrm{oc}}$ estimates of 2600,2500 , and 2100 can be derived.

Thus, in Wahid and Sethunathan's work, one would expect $K p$ to be proportional to organic carbon, with a proportionality constant, $K_{\mathrm{oc}}$, between $1 \times 10^{3}$ and $2.5 \times$ $10^{3}$. Unfortunately, these authors investigated the dependence of percent $\mathrm{HCH}$ sorbed, $F$, on organic carbon. $F$ is related to the partition coefficient by

$$
\frac{F}{100}=\frac{\rho K_{\mathrm{p}}}{1+\rho K_{\mathrm{p}}}
$$

where $\rho$ is the soil/water ratio, which in this case was 0.1 . If $K_{\mathrm{p}}$ varies linearly with organic carbon, a plot of $F$ vs. oc should be hyperbolic, as observed in Figure 1, rather 